\title{
COACHING: RGO (RENDAM GOSOK OLES/SOAK RUB TOPICAL/SRT) ON THE SELF CARE LEVEL OF LEPROSY CLIENTS
}

\author{
(Coaching: RGO (Rendam, Gosok, Oles) terhadap Tingkat Kemandirian \\ Perawatan Diri Klien Kusta)
}

\author{
Tantut Susanto*, Wantiyah** \\ *Department of Family and Community Nursing, School of Nursing, University of Jember \\ ***Department of Medical Surgical Nursing, School of Nursing, University of Jember \\ E-mail: susanto_unej@yahoo.com
}

\begin{abstract}
ABSTRAK
Pendahuluan. Permasalahan fisik klien kusta di masyarakat adalah seperti keadaan luka kusta yang semakin memburuk dan kecacatan yang muncul mengakibatkan masyarakat beranggapan negatif terhadap klien kusta. Tujuan Penelitian ini adalah untuk menganalisis pengaruh pemberian intervensi Coaching: RGO terhadap tingkat kemandirian perawatan diri klien kusta. Metode. Penelitian ini menggunakan metode eksperimen dengan rancangan one group design with pretest dan postest. Penelitian dilakukan selama 1 bulan pada klien kusta yang menjalani rehabilitasi berbasis masyarakat melalui pengambilan sampel secara simple random sampling dengan jumlah sampel 18 klien kusta di wilayah kerja Puskesmas Tempurejo dan Jenggawah. Hasil. Hasil penelitian menunjukkan tingkat kemandirian klien kusta sebelum intervensi RGO mayoritas mengalami ketergantungan total sebesar $83,3 \%$ dan setelah intervensi RGO mayoritas mengalami tingkat kemandirian mandiri sebesar 61,1\%. Analisis dengan menggunakan distribusi frekuensi dan kedall's tau menunjukkan adanya pengaruh pemberian coaching RGO terhadap tingkat kemandirian klien kusta (p 0,000; $\alpha$ 0,05). Diskusi. Klien kusta di masyarakat dan keluarga memerlukan latihan yang bertahap dan teratur sehari dua kali dalam perawatan mata, tangan, dan kaki melalui gerakan rendam, gosok, dan oles dalam upaya pencegahan tingkat kecacatan dengan mandiri.
\end{abstract}

Kata kunci: Coaching, Kusta, Rehabilitasi berbasis masyarakat

\begin{abstract}
Introduction. Physical problems of leprosy clients such as leprosy wounds and disability resulting negative public perception (stigma) for the clients. The purpose of this study was to analyze the effect of the intervention Coaching: RGO to the level of self-care of leprosy clients. Method. This study used an experimental design with one group pretest and posttest. The study was conducted during one month in leprosy clients undergoing rehabilitation through community. Eighteen (18) leprosy clients in Puskesmas Tempurejo and Jenggawah selected as respondents using simple random sampling. Result. The results showed that the level of self care before the RGO intervention the majority (83.3\%) of clients was dependent. After the intervention, the majority of clients (61.1\%) experience independence on performing self care. Analysis using frequency distribution and kendall's tau showed the effect of coaching on the level of self-care independence of the leprosy clients ( $p$ 0.000; $\alpha$ 0.05). Discussion. Leprosy clients require a gradual and regular exercise twice daily in the treatment of eyes, hands, and feet by doing soak, rub, and topical to prevent the disability.
\end{abstract}

Keywords: Coaching, Leprosy, community-based rehabilitation

\section{INTRODUCTION}

Jember is a leprosy endemic area, especially in sub-district Jenggawah and Tempurejo. Based on the data of Jenggawah Health Center in 2011-2014, the total of leprosy clients was 36 leprosy clients, 30 clients with leprosy type MB and 6 clients as PB leprosy. Whereas, at Tempurejo Health Center since 2011-2014 there were 27 cases of leprosy, with specifically 3 clients of PB leprosy and 24 clients of MB type. Jember Health Department (2012) showed that the percentage of defect in levels 2 at Jenggawah and Tempurejo was 25\% and $21 \%$. The data showed that the incidence of leprosy with the highest level of disability is still conceited.

Disability that occurs in leprosy clients will not occur if the client wants to do regular self-care associated with motoric and sensory disorders, and active in the treatment of MDT (Susanto, 2013). Leprosy clients in families and communities require a treatment as a form of community-based rehabilitation $(\mathrm{MOH}$, 2010). Community nurses can conduct home visits to teach the client to the treatment of 
leprosy in the eyes, hands, and feet to prevent the disability. The interventions can be done through coaching to train leprosy clients and families to do self-care at their home. The RGO (Soak, Scrub, and Rub) will reduce contractures of the hands and feet as well as prevent the occurrence of lesions that would occur as a result of leprosy neuroperifer deteriation (WHO, 2010).

Self-care performed by leprosy clients and family will have an impact on the clients independence on prevention of leprosy and disability level, so hopefully there will be an increase in quality of life for leprosy clients in the family and society. This study aims to identify the Effects of Coaching: RGO (Soak, Rub, Topical) to the level of independence of Leprosy clients in Jember.

\section{METHOD}

This study used experiments with one group randomized design with pretest and posttest. Samples were 18 leprosy clients residing in the Jenggawah and Tempurejo health center. Samples were taken by simple random sampling with the criteria were clients who are still in a period of leprosy MDT treatment in both health center. Samples will be measured related to the self-care of leprosy clients in caring their hand, eye, and foot. The Self-care activity refer to the guidelines of WHO (2000) and the Ministry of Health (2002).

Data collected through observation of the development of the measuring instrument observations of both guidelines. Clients will be measured on the level of self-care that will be divided into three categories depending on the total, depending on the part, and independent. Clients will experience two measurements, before and after administration of topical rub soak coaching. Firstly, the clients will be measured their activity of their eyes, hands, and feet care. After that, Leprosy client will be given training or coaching in self-care during the two-day coaching RGO. After getting therapy coaching the client was expected to perform self-care at home for a month.
The level of leprosy Clients' self-care before and after administration of coaching will be compared by using analysis of Kendal's Tau test with significance level 0.05 level.

\section{RESULTS}

Distribution of clients by age of leprosy and long-suffering leprosy in Jember especially Puskesmas Jenggawah and Tempurejo, the average age was 49.89 leprosy clients. Puskesmas and Puskesmas Tempurejo Jenggawah include Cangkring village, Jatisari, and Jenggawah to Puskesmas Jenggawah, as well as the village Curahtakir, Pondokrejo, Sidodadi, and Tempurejo for Tempurejo Work Area Health Center. In the early discovery of leprosy, only a few villages that became endemic leprosy. Based on the data obtained from Puskesmas Jenggawah, Cangkring is the village that became endemic leprosy. While the health center data Tempurejo, Pondokrejo village Curahtakir become the endemic equal potential for the development of leprosy is high enough.

Distribution characteristic by Gender leprosy clients mostly have male sex $(55.6 \%)$ with the amount of marital status as many as 16 leprosy clients have been married. The education level of leprosy clients most elementary level of education $(77.8 \%)$. The employment shows that most leprosy clients do not have a job that was as much as 7 (38.9\%). It also affects the income earned. Income will affect the treatment to be carried by leprosy clients. The majority of clients have an income below 1 million, only one patient who has insurance who controls their disease.

Type of leprosy showed that the majority of leprosy clients recorded experience with MB type of leprosy that is equal to 17 clients (94.4\%). Adherence to drug also has adverse impact on the level of disability of leprosy. The level of disability leprosy clients mostly level 0 is equal to $13(72.2 \%)$. The data obtained through the client leprosy showed that most clients who do the routine treatment of leprosy as many $(94.4 \%)$, has a disability that can be prevented or minimized. 


\section{Client Care Leprosy}

The problems experienced by leprosy clients can be prevented through self-care which includes eye care, hand care and foot care. This study provides a form of treatment therapies are taught to clients RGO leprosy to be done 2 times a day ie morning and evening for a month. In the measurement of progress, researchers measured levels of selfcare performed leprosy clients in conducting RGO therapy. The level of self-care before and after leprosy kilien will be measured and categorized into 3 levels of self-care, partial, and dependent. The level of client care before and after treatment of leprosy RGO can be seen in Table 1 below.

Table 1 showed that the level of client care leprosy prior to training delivery RGO shows much of the treatment as 15 respondents (83.3\%). After the administration of RGO therapy training, the level of self-care was standalone client leprosy were 11 persons (61.1\%). This indicates the delivery of training (coaching) and Rub Rub Soak therapy (RGO) on the client leprosy have an impact on the level of self-care leprosy clients become independent during the treatment 30 days after administration of the therapy.

\section{The difference in rate of Client's Leprosy Care}

Provision of training (coaching) on how to self-care clients with a simple treatment of leprosy are on hand and foot care through RGO' therapy. Clients receive training on RGO leprosy for 3 hours at the center. The level of self-care leprosy clients prior to training delivery and RGO measured after leprosy training clients RGO measured the level of care after 30 days. Clients are asked to make observations independently in the home associated with the schedule RGO performed for 2 times a day: morning and afternoon. The degree of difference in a client's treatment progress leprosy can be seen in Table 2 below.

Table 2 showed a significance value of 0.00 which is less than the alpha value of 0.05 so that it can be concluded no difference in the level of self-care leprosy clients before and after training coaching $\mathrm{RGO}$ ( $\mathrm{p}$ value $=$ $0.00 ; \alpha 0.005)$.

\section{DISCUSSION}

Characteristics of leprosy clients such as age, gender, marital status, education, occupation, income, insurance, type of leprosy, the level of disability experienced, long-suffering and treatment of leprosy. Age is one factor that affects the implementation of client care leprosy. The incidence of disability in patients with leprosy often occurs between the ages of 15-34 years, the age of a productive age. Physical activity is increased at the age of 15-34 years, so that the incidence of disability in leprosy patients more often experienced

Table 1. The Self care Level of Leprosy Client at Jember District (Jenggawah and Tempurejo Public Health Center) in $2014(\mathrm{n}=18)$

\begin{tabular}{lcccc}
\hline \multicolumn{1}{c}{$\quad$ Variable } & \multicolumn{2}{c}{ Before RGO } & \multicolumn{2}{c}{ After RGO } \\
\cline { 2 - 5 } \multicolumn{1}{c}{ Self care level } & Total & Percentage & Total & Percentage \\
\hline Independent & 1 & 5,6 & 11 & 61,1 \\
Partially & 2 & 11,1 & 7 & 38,9 \\
Fully dependent & 15 & 83,3 & 0 & 0 \\
\hline
\end{tabular}

Table 2. The Level of Leprosy Client's self care in Jember Regency (Jenggawah and Tempurejo District) in $2014(\mathrm{n}=18)$

\begin{tabular}{lcccccccc}
\hline \multicolumn{1}{c}{ Level of Self Care } & Mean & SD & N & Min-Max & $\begin{array}{c}\text { Mean } \\
\text { Rank }\end{array}$ & Kendall's W & Sig \\
\hline Before RGO & 1,22 & 0,54 & & & $1-3$ & 1,03 & & \\
\cline { 1 - 3 } & 2,61 & 0,50 & 18 & $2-3$ & 1,97 & 0,94 & 0,00 \\
\hline
\end{tabular}


at this age (Bakker et al., 2005). Variations of disability are more common in men than women. For handicapped hands and feet are common in men than women with disabilities ratio 2: 1 . Disability in men related to activities performed on a daily basis. Disability rate tends to be higher in males compared with females. This is related to work and smoking habits (Mohammed et al., 2004).

Low levels of education can result in slow search of treatment and diagnosis of disease. This can lead to disability in patients with more severe lerosy (Peter, 2002). The low educational level can affect patients with leprosy for not treating the wounds of leprosy so the condition will worsen the condition of disability (IYOR, 2005). Work hard and rough can aggravate the skin and nervous tissue damage getting worse. Jobs with the intensity of the old make eye activity increased so that the leprosy patients who experienced logopthalmus ie drought in the cornea results in keratitis (Wisnu and Hadilukito, 2003). The type of work the client has a disability that leprosy is most farmers (35\%). Jobs that require excessive physical activity can lead to more severe physical disability (Brakel and Kaur, 2002). It also affects the income earned. Income will affect treatment efforts will be made by the client leprosy. Less income is also supported by the insurance.

The incidence of disability is more often on the MB type of the PB (Richardus et al., 2003). Type of leprosy has a relationship with the level of disability (Ogbeiwi, 2005). The differences in the level of disability on MB and $\mathrm{PB}$ leprosy type due to the type of MB leprosy treatment longer than on the type of PB. Diagnosis of leprosy done everything from execute anamnesis, clinical examination, bacteriological examination, histopathological and immunological (MOH, 2005). Adherence to drug also has adverse impact on the level of disability of leprosy. The data obtained through the client leprosy showed that the majority (94.4\%) leprosy clients treatment. In patients with type PB leprosy are treated on a regular basis will quickly heal without causing defects. If the leprosy patients do not take medication on a regular basis, then the leprosy bacteria can become active again, causing new symptoms on the skin and nerves that can make things worse (Ogbeiwi, 2005). One of the works done is to check their families with family members with leprosy to health care and leprosy eradication program.

Leprosy eradication program is a program create with the purpose of curing leprosy patients and prevent the onset of disability and break the chain of transmission of leprosy patients, especially the type that is contagious to others to reduce the incidence of disease. One way of doing that is drug delivery MDT (Multi Drug Therapy). MDT (Multi Drug Therapy) with a combination of rifampicin, clofazimine, and DDS started in 1981. This treatment aims to address the increasing dapsone resistance, reducing patient non-compliance, lower withdrawal rate, and eliminating leprosy germs persistence in tissues (Mulluzi, 2013). The level of disability leprosy clients in Jember district health centers, especially in the Work Area and Tempurejo Jenggawah By 2014 the majority of defects at the level of $0(72.2 \%)$, and the rest experience a level of disability 2 (28.8\%). 1 defect rate is still found in Puskesmas Jenggawah and Tempurejo. The role of the family and health care workers as an important coaching in minimizing the level of disability in leprosy clients is through client self-care leprosy.

The results of the study before coaching RGO was found that the majority (83.3\%) level of self-care clients depending on the total leprosy. This is what will affect the maximum and whether or not the level of disability experienced, because RGO exercise are important factors that play a role in the healing process and minimize the client's level of disability of leprosy. Families can be optimized as a coach in training RGO, so that families can play in a number of ways to minimize the level of disability in leprosy treatment such as keeping clients regularly, and perform self-care on the client's self leprosy. In patients with type PB leprosy are treated on a regular basis will quickly heal without causing defects. If the leprosy patients do not take medication on a regular basis, then the leprosy bacteria can become active again, causing new 
symptoms on the skin and nerves that can make things worse (Ogbeiwi, 2005).

Self-care plays an important role in the high rates of disability that can be experienced by leprosy clients. Based on the research of Ganapati et al. (2003), conducted on 454 patients with leprosy result that after 4 years of leprosy detected with good self-care can help improve the level of disability of more than $50 \%$ of the patients. Lack of self-care in patients with leprosy can result in more severe damage will increase. The result showed RGO through coaching techniques can increase the level of self-care leprosy clients from total dependence $83.3 \%$ to $61.1 \%$ self-sufficient after one month of training at home RGO.

The level of self-care leprosy client before therapy RGO coaching through the bulk of $83.3 \%$ is the total dependence. Leprosy clients just follow a regular treatment to pusksesmas and sometimes forget to do self-care at home. Family and clients to treat leprosy in this study relates to the wound and dry or rough skin, food, toiletries, and support for taking medication. This is done to prevent disability in leprosy clients. Junaid (2002) conducted research on disability leprosy and its determinant in the health center Batimurung Maros. The results showed that there was a relationship between the regularity of treatment, duration of illness, duration of treatment and the type of leprosy with the incidence of disability in leprosy clients.

The treatment performed by the client before coaching RGO leprosy based on knowledge obtained independently or based on the knowledge gained from the clinic. Clients in treatment in this study there are able and some are not able to provide care to clients with leprosy, so we get the degree of independence of independent clients by 5.6\%, $11.1 \%$ partially independent and a dependent total of $83,3 \%$ (WHO, 2000) developed an action to prevent the limitations and physical disability in leprosy clients in the community. Precautions emphasis is on foot care, hand care, and eye care (WHO, 2000).

The level of self-care leprosy clients after therapy was able to reduce the level of dependency, which were the total dependence leprosy' became independent in self-care in part independently of $38.9 \%$ and $61.1 \%$. WHO (2000), treatment of the feet with dry skin and cracking can be done by encouraging leprosy clients to soak feet for 20 minutes every day in the water and smearing her feet with oil or vaseline on a regular basis and encourage clients to use shoes or sandals to protect your feet clients from injury or trauma. Prevention of trauma to the client leprosy can also be done through nurturing family environment leprosy clients.

Leprosy clients after therapy RGO required use footwear such as sandals or shoes to avoid injury in the leg. Cross (2001; in Britton, 2004) self-care measures that are taught to leprosy clients proved to be very effective in preventing ulceration of the hands and feet of leprosy clients. Kazen (1999; in Britton, 2004) precautions on foot ulceration can also be made through the sole of the foot rest. Ulcerations on the feet appear as a result of increased pressure on the bone that is the main support of the foot and will be intermittent due to deformity and loss of sensation. On the client leprosy that has ulceration of the foot will re-heal if kept from excessive use (weight-bearing). Rest use of the foot (no weight-bearing) should be carried out until the leg ulcer healed. Complications due to ulceration require surgery to get rid of dead tissue with exploration and drainage. The use of antibiotics should be used only on a bone infection or septicemia. Srinivasin (1994; in Britton, 2004) contractures of the hands and feet and drop foot can be prevented by treatment of mobility, but if contractures of the hands and foot drop weight and the presence of conditions lagophthalmos, entropion, and ectropion reconstruction is recommended to be done surgically.

Statistical analysis showed a significance value of 0.00 which is less than the alpha value of 0.05 so that it can be concluded no difference in the level of self-care leprosy clients before and after training coaching RGO ( $p$ value $=0.00 ; \alpha 0.005$ ). Coaching or counseling is a process of intensive learning through individual guidance, demonstrations, and practices followed by the provision of 
immediate feedback. The purpose of coaching on the client and family leprosy is to improve, develop, or implement instructional materials or procedures, for example in the treatment of eyes, hands, and feet leprosy clients (Gladding, 2010). Nursing became an important role in improving the health status of the client leprosy which health promotion and improvement of social support in the realization of the attitude to be a real action takes supporting factors such facilities. Family support and motivation in the form of social support is to carry out the functions of family health care in the prevention of leprosy disability clients.

\section{CONCLUSION}

The coaching: RGO (Soak, Rub, Topical) can increase a degree of self care independence of leprosy clients.

\section{RECOMMENDATION}

Leprosy clients require a gradual and regular exercise twice daily in the treatment of eyes, hands, and feet by doing soak, rub, and topical to prevent the disability.

\section{REFERENCES}

Bakker M., Hatta M., Kwenang A., Klaster PR, Oskam L. 2005. Epidemiology and Prevention of Leprosy: a Cohort Study In Indonesia; Epidemiology of Leprosy on Five Isolated Islands in The Flores Sea. Nethderlands.

Brakel, V.W., Kaur, H. 2002. Leprosy Review; Is Beggary a Chosen Profession Among People Living in Leprosy Colony, The Leprosy Mission India., India: New Delhi 110 001. 2 Mei 2014.

Britton, W.J., Diana NJ Lockwood. 2004. Leprosy. The Lancet; Apr 10, 2004; 363, 9416; Diakses dari ProQuest Nursing \& Allied Health Source pg. 1209. Diakses dari http://www.Proquest.com/pqdauto/ Nursing and Allied Health Source. Tanggal 16 Desember 2009.
Depkes RI. 2005. Buku Pedoman Nasional Pemberantasan Penyakit Kusta. Cetakan XVII. Jakarta: Direktorat Jendral PPM dan PLP.

Depkes RI. 2006. Buku Pedoman Nasional Pemberantasan Penyakit Kusta. Jakarta: Direktorat Jenderal Pengendalian Penyakit dan Penyehatan Lingkungan

Ganapati, R., Pai, VV., Kingsley S. 2003. Disability Prevention and Management in Leprosy: A Field Experience. Vol. 69. Indian J Dermatol Venereol Leprol.

Gladding, Samuel T,. (2002). Family Therapy: History, Theory, and Practise. $3 r d$ ed. New Jersey: Precinte-Hall.

Iyor T.F. 2005. Knowledge and Attitude of Nigerian Physiotherapy Students About Leprosy. Vol. 16. Asia Pacific Disability Rehabilitation Journal.

Junaid, K. (2002). Kecacatan Kusta dan Determinannya di Wilayah Puskesmas Bantimurung Kabupaten Maros. Diakses dari http://digilib.litbang.depkes. go.id/go.php?id=jkpkbppk-gdl-res-2002kaya2c-1932-kecacatan \&q=kusta . Tanggal 30 Mei 2010.

Muhammed K., Nandakumar G., Thomas S. 2004. Disability Rates in Leprosy. Vol. 70. Hal. 314-316. Indian J Dermatol Venereol Leprol.

Mulluzi, Ali Sibra. 2013. Studi epidemiologi penyakit kusta di wilayah kerja Puskesmas Tanggul. Jember: Dinas Kesehatan Kabupaten Jember.

Ogbeiwi, OI. 2005. Progress Towards the Elimination of Leprosy in Nigeria: a Review of the Role of Policy Implementasion and Operational Factors. Vol. 76. Leprosy Review.

Peter, E.S., Eshiet, A.L. 2002. Leprosy Review: Male-female Differences in Leprosy Patients in South Eastern Nigeria: Females Present Late For Diagnosis and Treatment and Have Higher Rate of Deformity. 21 Maret 2014.

Richardus JH., Meima A., Croft RP., Habema JD. 2003. Case detection, gender and disability in leprosy in Bangladesh: a trend analysis. Vol. 75. Indian J Public Health. 
Jurnal INJEC Vol. 2 No. 1 April 2015: 126-132

Susanto, et al. 2013. Perawatan Klien Kusta di Komunitas. Jakarta: Trans Info Media.

Susanto, Tantut. 2010. Pengalaman Klien Dewasa Menjalani Perawatan Kusta di Wilayah Kerja Puskesmas Jenggawah Kabupaten Jember Jawa Timur: Studi Fenomenologi. Tesis FIK UI (Tidak Dipublikasikan)
WHO. 2000. Guide to Eliminate Leprosy as a Public Health Problem First Edition. Geneva: WHO.

WHO. 2011. Diagnosis of Leprosy. [serial online]. http://www.who.int/lep/ diagnosis/en/, [8 Januari 2011].

Wisnu., Hadilukito, G. 2003. Kusta; Pencegahan Cacat Kusta. Ed. 2. Jakarta: Balai Penerbit FKUI. 